\section{Showpiece reactor on ice}

\section{Munich}

THE malaise that has afflicted West Germany's nuclear industry grew worse recently when Research and Technology Minister Heinz Riesenhuber refused to increase government investment in a showpiece nuclear reactor. The decision cast doubt on the ability of the reactor to operate economically, an important selling point for the West German companies that intend to market reactors of this type worldwide.

Following the apparent abandonment by West Germany of the nuclear fuel reprocessing plant at Wackersdorf (see Nature 33, 611; 1989), Riesenhuber's announcement reinforce the impression that the government is wavering in its support for nuclear power. Riesenhuber and other government officials have denied this interpretation.

The showpiece reactor is a prototype high-temperature, gas-cooled reactor (HTR) with a generating capacity of $300 \mathrm{MW}$. Located at Hamm-Uentrop in northwestern Germany, it was the first HTR of its size in the world. The West German government paid 80 per cent of the estimated DM4,000-million final cost of building the reactor. Maintaining the non-operative reactor costs DM18 million per month.

Potential HTR producers such as Siemens and Asea Brown Boveri (ABB) are seeking overseas markets to make up for stagnating demand for reactors in West Germany, Switzerland and other Western European countries. Siemens and $\mathrm{ABB}$ have explored the possibility of exporting reactors to the Soviet Union and China, but no plans have been made.

Proponents of this reactor type say that it is inherently safe and that the high temperatures produced at the core - up to $950{ }^{\circ} \mathrm{C}$ - can be used as a second source of energy, for example to liquefy coal. But ironically, concern about safety led to the initial shutdown of the West German HTR in October 1988. The reactor has not operated since then.

Riesenhuber said no to a request from the reactor operators, Hochtemperatur Kernkraft GmbH (HKG), to increase government investment in the operating costs of the plant from the current DM450 million to over DM1,000 million. Much of this increase would have been used to produce new fuel elements for the HTR. The current supply of fuel will last for only two to three more years.

The only question seemingly still open is whether the HTR will operate at all using the remaining fuel elements before being decommissioned as early as 1991 . $\mathrm{HKG}$ has requested further operation; Riesenhuber and local authorities have rejected it.
Decommissioning costs could run as high as DM400 million if the site of the HTR is returned to the 'green field' it used to be, as the government has promised.

Other countries are confident that HTRs will comprise the next generation of nuclear reactors. Japan has built a test reactor and the United States has for years operated an HTR in Fort St Vrain, Colorado. The US Department of Energy is proposing building an HTR in Idaho to produce tritium for nuclear weapons.

The future of the partly built nuclear fuel reprocessing plant at Wackersdorf was still uncertain last week, although a number of factors point to the plant being shut down. Even the Bavarian government, which initially defended the project, has agreed in principle to a

\section{US NUCLEAR POWER}

\section{Disposal plan for old military reactors}

\section{Richland, Washington}

THE fate of the nation's eight retired plutonium production reactors at the Hanford Military Site in Washington State became clearer recently when the US Department of Energy released an environmental impact statement outlining disposal options. The controversial impact statement has been awaited by many nearby residents and other environmentalists ever since the last of these reactors was shut down in 1971.

The Hanford site has produced a sizeable share of the weapons-grade plutonium in the United States. The military reactors now considered for decommissioning include the nation's first such reactor which produced the plutonium used in the atomic bomb dropped on Nagasaki during the Second World War. Apart from the eight reactors included in the report, only one more recent plant, $\mathrm{N}$-reactor, exists at the Hanford site, and it too has been shut since 1987 because of safety concerns.

Energy Secretary James Watkins has ordered that the slightly newer N-reactor be kept indefinitely in 'cold standby' status. But Hanford officials announced that nuclear fuel had been removed from $\mathrm{N}$ reactor, quelling speculation that plutonium production at the site might soon resume.

The decommissioning options outlined in the Energy Department's report range in estimated cost from $\$ 41$ million for no action to more than $\$ 200$ million in fixed 1986 dollars. These estimates make up only a tiny fraction of the department's estimated $\$ 57,000$ million needed to effect a complete clean-up at the Hanford site.

An odd twist to the decommissioning shutdown. Politicians and utility officials met in Bonn last week to debate Wackersdorf's future, but reached no decision.

At the same time, West German Environment Minister Töpfer, who is also responsible for reactor safety, travelled to Paris to discuss the French offer to take over West German reprocessing and sell West German companies a share of the French reprocessing facility at La Hague.

The end of Wackersdorf could also cause significant cuts in the West German research budget. West Germany at present spends about DM120 million a year on improving reprocessing technology. Up to one-third of this could be affected by the decision on Wackersdorf. The other twothirds are spent on quality control and radiation-emission control of nuclear fuel elements, areas that will continue to be important even if Wackersdorf is shut.

Steven Dickman

process is that the oldest facility at Hanford has been designated a national historic mechanical engineering landmark by the American Society of Mechanical Engineers. The B-reactor went on-line in 1944 under the direction of Enrico Fermi, and discussions are now under way about maintaining the reactor as a tourist attraction.

Seth Shulman

\section{Reactors in Wonderland}

\section{Boston}

THE Shoreham and Seabrook nuclear power plants continue to lurch slowly but steadily toward operation. With positive proclamations from the Nuclear Regulatory Commission (NRC) in each reactor's case, licensing no longer seems to be a serious obstacle for either plant. At this point, only state and local opposition will prevent the plants from going on line. At the Seabrook, New Hampshire, plant, Massachusetts Attorney General James Shannon is challenging in court a lowpower license NRC is expected to issue. In New York, Governor Mario Cuomo's plan to buy the Shoreham plant from the Long Island utility for a token sum of $\$ 1$, and then dismantle it, still technically holds the day. But this plan has been weakened by NRC's decision to issue a full-power license for the plant, and the strong pronouncements from many leaders in the energy field supporting Shoreham's operation.

James D. Watkins, US Secretary of Energy, recently called the Cuomo plan for Seabrook "one of the most foolish deals in the nation's history". Calling the dismantling plans "utterly irresponsible", Watkins added "one dollar for a $\$ 5.6$ billion testament to American technological knowhow, only to dismantle it? Even Alice's Wonderland does not contain such anomalies."

Seth Shulman 